Original Research Article

\title{
Evaluation of the analgesic and antipyretic properties of African Cleome viscosa
}

\author{
Chukwuka O. Opara ${ }^{1 *}$, Kauna Usman ${ }^{2}$
}

${ }^{1}$ Department of Pharmacy, National Hospital Abuja, Nigeria ${ }^{2}$ Department of Pharmacology, Federal University Dutse, Jigawa state Nigeria

Received: 23 April 2018 Accepted: 23 May 2018

\section{*Correspondence to: \\ Chukwuka O. Opara, Email: talktochuka@ hotmail.com}

Copyright: (c) the author(s), publisher and licensee Medip Academy. This is an openaccess article distributed under the terms of the Creative Commons Attribution NonCommercial License, which permits unrestricted noncommercial use, distribution, and reproduction in any medium, provided the original work is properly cited.

\begin{abstract}
Background: Cleome viscosa Linn a plant from the family Capparaceae has been used in traditional medicine in Asia and Africa for the treatment of various diseases including diarrhea, cardiac stimulant, anthelmintic, carminative, antiinflammatory and antiseptic. Decoction of the whole plant has been used for the treatment of inflammation and as a stimulant while the leaves have been applied externally on wounds and ulcers. The objective of this study is to investigate and evaluate the antipyretic and analgesic properties, toxicity profile and the phytochemical study of the methanolic leaf extract of African Cleome viscosa. Methods: The antipyretic study was performed by adopting the Baker's yeast induced pyrexia in rats while the analgesic study was performed adopting the tail immersion or tail flick technique. Data generated was analyzed as appropriate using the analysis of variance (ANOVA).

Results: The methanolic extract of the leaves of the African Cleome viscosa had a significant $(\mathrm{P}<0.05)$ antipyretic and analgesic effects at different time intervals and varying doses when compared with the negative control groups in the respective studies. The preliminary phytochemical study showed the presence of alkaloids, tannins, steroids, glycosides and flavonoids. The extract also proved to be non-toxic in the acute toxicity study carried out at the highest dose of $5000 \mathrm{mg} / \mathrm{kg}$ body weight administered to the albino rats.

Conclusions: The methanolic leaf extract of the plant showed significant antipyretic and analgesic activity in albino rats thus supporting its use in traditional medicine.
\end{abstract}

Keywords: Antipyretic and Analgesic, Baker's yeast, Cleome viscose, Methanolic extract

\section{INTRODUCTION}

In Africa, Cleome viscosa (Tafarnwakura in Hausa, Nigeria) has been used traditionally for the treatment of several medical conditions including pain and pyrexia and has shown reasonable antipyretic, analgesic and antidiarrheal effects in Asia. ${ }^{1,2}$

Pain being the most common reason for most medical consultations in many health institutions today is an unpleasant episode which could be emotional or sensory linked tissue damage. ${ }^{3}$ The pain pathway is initiated by receptors called nociceptors in the peripheral and central nervous systems in response to malfunctions done on these systems. ${ }^{4,5}$ Pyrexia also referred to as controlled hyperthermia is elevated body temperature above the normal range $36.5^{\circ} \mathrm{C}-37.5^{\circ} \mathrm{C}$ due to the presence of pyrogens. $^{6-8}$

Inadequate treatment of highly discomforting symptoms including pain and pyrexia coupled with the major side effects associated with some existing analgesic and antipyretic agents including hepatotoxicity, nephrotoxicity, hypersensitivity and ulcerogenicity has led to the rapid acceptance of herbal medicines in Africa. ${ }^{9,10}$ Most herbal medications have been reported to have more than one therapeutic use, thus there is great need for the 
more research into tropically available traditional medicines which have been reported to be effective when used locally. ${ }^{11}$ The analgesic and antipyretic activities of the plant Cleome viscosa has been determined in India however, the African specie has not been evaluated hence this research is aimed at investigating the possible potential analgesic and antipyretic effects of the methanolic leaf extract of the African Cleome viscosa. ${ }^{12}$ This aim however is to either support or refute the claims arising from its local use in traditional medicine and for the recommendation of the plant for further studies by other researchers using the results that will be obtained in this study.

\section{METHODS}

\section{Preparation of the extract}

The whole plant of Cleome viscosa was collected from the wild around Maiduguri Metropolitan Council of Nigeria with the aid of a traditional medical practitioner (TMP) whom identified the plant which was further authenticated by a taxonomist from the department of biological sciences, University of Maiduguri.

The plant material was washed clean and the leaves were then removed, air dried, pulverized and then stored in air tight containers at room temperature in the pharmacognosy laboratory of the faculty of Pharmaceutical sciences, University of Maiduguri prior to extraction. A known weight of $4.5 \mathrm{~kg}$ of the powdered plant drug was macerated in three different $4 \mathrm{~L}$ reagent bottles with each bottle containing $1.5 \mathrm{~kg}$ of the powdered plant macerated in 2.5liters of methanol (95\%). These were macerated for 48 hours and then filtered twice to obtain the clear filtrate using glass funnels appropriately plugged with cotton wool each time.

The filtrate was then concentrated using rotary evaporator and then exposed to dry under air and the semi-solid extract was then subsequently defattened using $4.0 \mathrm{~L}$ of petroleum ether. This process was performed successively and continuously until no trace of fat was seemingly found in the petroleum ether fraction in which the extract was macerated. The resultant residue was air dried and the $47 \mathrm{~g}$ brownish extract which was noticed to be hygroscopic was stored in an air tight container and kept at room temperature in the pharmacology laboratory of the faculty of Pharmaceutical science of the University of Maiduguri until use.

\section{Animals}

Albino rats of both sexes weighing between $150 \mathrm{~g}-220 \mathrm{~g}$ were used for the study. The animals were obtained from the animal house of the pharmacology and clinical pharmacy department of Ahmadu Bello University Zaria and were maintained in the pharmacology laboratory of the faculty of Pharmaceutical sciences, University of Maiduguri at standard conditions of temperature, relative humidity and 12 hours light and darkness cycle. The rats were feed with pelletized Vital feed growers (Grand cereal LTD, UAC subsidiary Jos, Nigeria) and water given $a d$ libitum.

\section{Acute toxicity study}

A pilot study was conducted using the modified Lorke's 1983 method on three groups of 2 rats each weighing between $160 \mathrm{~g}-200 \mathrm{~g}$. A reconstituted solution of the methanolic extract in $20 \% \mathrm{v} / \mathrm{v}$ tween 80 in water for injection at different concentrations $(100 \mathrm{mg} / \mathrm{ml}$, $200 \mathrm{mg} / \mathrm{ml}, 500 \mathrm{mg} / \mathrm{ml}$ and $600 \mathrm{mg} / \mathrm{ml}$ ) was administered to the rats orally via a nasogastric tube.

Chosen doses were influenced by a pre-existing literature on an acute toxicity study on the methanolic extract of Cleome viscosa which showed no toxicity at a higher dose of $3.2 \mathrm{~g} / \mathrm{kg} .{ }^{1}$ Therefore, doses of $1000 \mathrm{mg} / \mathrm{kg}, 3000 \mathrm{mg} / \mathrm{kg}$ and $5000 \mathrm{mg} / \mathrm{kg}$ were adopted for the acute toxicity study and the animals were monitored for any signs or occurrences of death within 48 hours to ascertain the lethal dose $\left(\mathrm{LD}_{50}\right)$.

\section{Preliminary phytochemical studies}

The methanolic extract of the plant Cleome viscosa was screened preliminarily for the presence of phytochemicals employing the standard screening procedure. ${ }^{10}$

\section{Antipyretic study}

\section{Induction of pyrexia}

The method described by Vogel, was employed, this involved monitoring the background baseline temperature of the rats and obtaining an average routine temperature. ${ }^{13}$ 20 animals were weighed and then a preparation of $15 \%$ yeast suspension in $0.9 \%$ saline solution was prepared and injected into the animals subcutaneously at a dose of $10 \mathrm{ml} / \mathrm{kg}$. The animals were then monitored for $18 \mathrm{hrs}$ and were only administered water ad libitum during that duration.

\section{Test}

1. After $18 \mathrm{hrs}$ a base line temperature was obtained and was found to be between $\left(35.3^{\circ} \mathrm{C}-38.3^{\circ} \mathrm{C}\right)$ then 15 animals were selected and separated randomly into 5 groups of 3 each, the animals were tagged in groups labeled A-E.

2. Different concentrations and dilutions of the solution of the extract were prepared with $20 \% \mathrm{v} / \mathrm{v}$ tween 80 , in water for injection at $100 \mathrm{mg} / \mathrm{ml}, 200 \mathrm{mg} / \mathrm{ml}$, $500 \mathrm{mg} / \mathrm{ml}$ and $600 \mathrm{mg} / \mathrm{ml}$ concentrations.

3. The rats were again weighed and treated with the test sample by oral administration.

4. Group A received the standard drug Paracetamol at $150 \mathrm{mg} / \mathrm{kg}$ dose and served as positive control group. 
5. Group B received $1 \mathrm{ml} 20 \% \mathrm{v} / \mathrm{v}$ tween 80 in water for injection and served as negative control.

6. Groups $\mathrm{C}, \mathrm{D}$ and $\mathrm{E}$ received the extract solution at doses of $200 \mathrm{mg} / \mathrm{kg}, \quad 400 \mathrm{mg} / \mathrm{kg}$ and $600 \mathrm{mg} / \mathrm{kg}$ respectively. The rate of decrease in temperature caused by each treatment was then monitored every 30 minutes for 4 hours and then after 24 hours.

\section{Analgesic study}

\section{Induction of pain}

The method previously described was adopted. ${ }^{14,15}$ This involved monitoring the sensitivities of the rats to environmental stimuli over 24 hours and marking of the $5 \mathrm{~cm}$ length from the tip of the tails of the rats. This was followed by the insertion of not more than $5 \mathrm{~cm}$ of the tip of the rat's tail in a water bath maintained at about $45-60^{\circ} \mathrm{c}$ temperature to watch for the reaction time to pain measured in seconds.

\section{Test}

1. After monitoring of the routine base line sensitivities of the rats, 15 animals were separated randomly into five groups of 3 rats each. The animals were tagged in groups labeled A-E

2. The rats were weighed and the base line reaction time determined. The reaction time was found to be between 2.44 - 4.07seconds

3. Different concentrations of the extract was then made with $20 \% \mathrm{v} / \mathrm{v}$ tween 80 in water for injection at $100 \mathrm{mg} / \mathrm{ml}, 200 \mathrm{mg} / \mathrm{ml}, 500 \mathrm{mg} / \mathrm{ml}$ and $600 \mathrm{mg} / \mathrm{ml}$ concentrations.

4. Each group was then pretreated with the test items with Group A receiving Dihydrocodeine $(0.5 \mathrm{mg} / \mathrm{kg})$ and serving as positive control.

5. Group B received $1 \mathrm{ml}$ of $20 \% \mathrm{v} / \mathrm{v}$ tween 80 in water serving as negative control.
6. Group C, D and E received the extract solution at doses of $200 \mathrm{mg} / \mathrm{kg}, \quad 400 \mathrm{mg} / \mathrm{kg}$ and $600 \mathrm{mg} / \mathrm{kg}$ respectively. The reaction time after tail immersion in a $550 \mathrm{C}$ maintained hot water-bath was monitored every 30 minutes for 4 hours and recorded in seconds.

This study was conducted under the cover of the animal and human rights procedures and ethical procedures of the University of Maiduguri, Borno state, Nigeria as over seen by Prof. Isah Hussaini and Dr. Garba U. Sadiq.

\section{Statistical analysis}

All the results generated were analyzed as appropriate using the analysis of variance (ANOVA) and a statistical significance of $(\mathrm{P}<0.05)$.

\section{RESULTS}

\section{Acute toxicity study}

The acute toxicity study showed that except for a decrease in body base line temperature there were no symptoms of poisoning and mortality including decreased respiratory rate and locomotory activity in all the experimental rats used for up to 48 hours after extract administration. This non-toxic effect was also demonstrated even at the highest dose $(5000 \mathrm{mg} / \mathrm{kg})$.

\section{Preliminary phytochemical studies}

Treatment of the extract with various chemicals showed indications that suggested the presence of alkaloids, steroids, tannins, flavonoids and glycosides.

\section{Antipyretic and analgesic studies}

The results of the antipyretic and analgesic studies are as presented on tables 1 and 2 below.

Table 1: Comparison of rectal temperature post induction of pyrexia against the negative control at respective time intervals.

\begin{tabular}{|c|c|c|c|c|c|c|c|c|c|}
\hline $\begin{array}{l}\text { Treatment given } \\
\text { post induction of } \\
\text { pyrexia }\end{array}$ & $30 \mathrm{~min}$ & 1 hour & $\begin{array}{l}1.30 \\
\text { hours }\end{array}$ & 2 hours & $\begin{array}{l}2.30 \\
\text { hours }\end{array}$ & 3 hours & $\begin{array}{l}3.30 \\
\text { hours }\end{array}$ & 4 hours & $\begin{array}{l}24 \\
\text { hours }\end{array}$ \\
\hline $\begin{array}{l}\text { Negative control } \\
(20 \% \mathrm{v} / \mathrm{v} \text { tween } 80 \\
\text { in water for } \\
\text { injection) }\end{array}$ & $\begin{array}{l}-0.83 \\
( \pm 0.31)\end{array}$ & $\begin{array}{l}-0.87 \\
( \pm 0.51)\end{array}$ & $\begin{array}{l}-0.63 \\
( \pm 0.43)\end{array}$ & $\begin{array}{l}-1.23 \\
( \pm 0.29)\end{array}$ & $\begin{array}{l}-1.10 \\
( \pm 0.36)\end{array}$ & $\begin{array}{l}-1.23 \\
( \pm 0.15)\end{array}$ & $\begin{array}{l}-1.20 \\
( \pm 0.35)\end{array}$ & $\begin{array}{l}-1.53 \\
( \pm 0.15)\end{array}$ & $\begin{array}{l}-0.30 \\
( \pm 0.35)\end{array}$ \\
\hline Extract $200 \mathrm{mg} / \mathrm{kg}$ & $\begin{array}{l}0.27 \\
( \pm 0.21)^{*}\end{array}$ & $\begin{array}{l}0.47 \\
( \pm 0.31)^{*}\end{array}$ & $\begin{array}{l}0.63 \\
( \pm 0.40)^{*}\end{array}$ & $\begin{array}{l}0.00 \\
( \pm 0.50)^{*}\end{array}$ & $\begin{array}{l}-0.40 \\
( \pm 0.35)\end{array}$ & $\begin{array}{l}-0.45 \\
( \pm 0.64)\end{array}$ & $\begin{array}{l}-0.40 \\
( \pm 0.00)^{*}\end{array}$ & $\begin{array}{l}-0.40 \\
( \pm 0.14)^{*}\end{array}$ & $\begin{array}{l}-0.25 \\
( \pm 2.35)\end{array}$ \\
\hline Extract $400 \mathrm{mg} / \mathrm{kg}$ & $\begin{array}{l}0.60 \\
( \pm 0.95)^{*}\end{array}$ & $\begin{array}{l}1.13 \\
( \pm 1.18)^{*}\end{array}$ & $\begin{array}{l}1.13 \\
( \pm 0.51)^{*}\end{array}$ & $\begin{array}{l}0.40 \\
( \pm 0.96)^{*}\end{array}$ & $\begin{array}{l}0.23 \\
( \pm 0.76)^{*}\end{array}$ & $\begin{array}{l}-0.87 \\
( \pm 0.25)\end{array}$ & $\begin{array}{l}-1.00 \\
( \pm 0.44)\end{array}$ & $\begin{array}{l}-1.43 \\
( \pm 0.38)\end{array}$ & $\begin{array}{l}1.00 \\
( \pm 0.70)\end{array}$ \\
\hline Extract $600 \mathrm{mg} / \mathrm{kg}$ & $\begin{array}{l}0.23 \\
( \pm 0.15)^{*}\end{array}$ & $\begin{array}{l}0.57 \\
( \pm 0.38)^{*}\end{array}$ & $\begin{array}{l}1.10 \\
( \pm 0.30)^{*}\end{array}$ & $\begin{array}{l}0.53 \\
( \pm 0.51)^{*}\end{array}$ & $\begin{array}{l}0.17 \\
( \pm 0.31)^{*}\end{array}$ & $\begin{array}{l}-0.10 \\
( \pm 0.78) *\end{array}$ & $\begin{array}{l}-0.33 \\
( \pm 0.25)^{*}\end{array}$ & $\begin{array}{l}-0.07 \\
( \pm 0.21)^{*}\end{array}$ & $\begin{array}{l}1.87 \\
( \pm 0.68) *\end{array}$ \\
\hline $\begin{array}{l}\text { Paracetamol } \\
150 \mathrm{mg} / \mathrm{kg} \text { (positive } \\
\text { control) }\end{array}$ & $\begin{array}{l}0.37 \\
( \pm 0.12)^{*}\end{array}$ & $\begin{array}{l}1.77 \\
( \pm 0.42)^{*}\end{array}$ & $\begin{array}{l}0.67 \\
( \pm 0.99)^{*}\end{array}$ & $\begin{array}{l}0.17 \\
( \pm 0.38)^{*}\end{array}$ & $\begin{array}{l}-0.03 \\
( \pm 0.72)^{*}\end{array}$ & $\begin{array}{l}-0.50 \\
( \pm 0.62)\end{array}$ & $\begin{array}{l}-0.57 \\
( \pm 0.31)^{*}\end{array}$ & $\begin{array}{l}-1.00 \\
( \pm 0.70)\end{array}$ & $\begin{array}{l}0.33 \\
( \pm 0.60)\end{array}$ \\
\hline
\end{tabular}

*This indicates the time intervals that are significant $(\mathrm{P}<0.05)$ when compared to the negative control, for the respective interventions 
Table 2: Comparison of latency of reaction time (LRT) to pain pretreatment against negative control at respective time intervals.

\begin{tabular}{|c|c|c|c|c|c|c|c|c|}
\hline Pretreatment before induction of pain & $30 \mathrm{~min}$ & 1 hour & $\begin{array}{l}1.30 \\
\text { hours }\end{array}$ & 2 hours & $\begin{array}{l}2.30 \\
\text { hours }\end{array}$ & 3 hours & $\begin{array}{l}3.30 \\
\text { hours }\end{array}$ & $\begin{array}{l}4 \\
\text { hours }\end{array}$ \\
\hline $\begin{array}{l}\text { Negative control ( } 20 \% \mathrm{v} / \mathrm{v} \text { tween } 80 \text { in } \\
\text { water for injection) }\end{array}$ & $\begin{array}{l}2.85 \\
( \pm 0.19)\end{array}$ & $\begin{array}{l}2.50 \\
( \pm 0.16)\end{array}$ & $\begin{array}{l}2.60 \\
( \pm 0.13)\end{array}$ & $\begin{array}{l}2.78 \\
( \pm 0.73)\end{array}$ & $\begin{array}{l}2.74 \\
( \pm 0.76)\end{array}$ & $\begin{array}{l}2.76 \\
( \pm 0.81)\end{array}$ & $\begin{array}{l}2.53 \\
( \pm 0.54)\end{array}$ & $\begin{array}{l}3.03 \\
( \pm 0.31)\end{array}$ \\
\hline Extract $200 \mathrm{mg} / \mathrm{kg}$ & $\begin{array}{l}3.23 \\
( \pm 0.08)\end{array}$ & $\begin{array}{l}3.58 \\
( \pm 0.33)^{*}\end{array}$ & $\begin{array}{l}3.60 \\
( \pm 0.33)^{*}\end{array}$ & $\begin{array}{l}3.64 \\
( \pm 0.35)\end{array}$ & $\begin{array}{l}3.51 \\
( \pm 0.32)\end{array}$ & $\begin{array}{l}2.83 \\
( \pm 0.36)\end{array}$ & $\begin{array}{l}2.23 \\
( \pm 0.27)\end{array}$ & $\begin{array}{l}2.80 \\
( \pm 0.44)\end{array}$ \\
\hline Extract $400 \mathrm{mg} / \mathrm{kg}$ & $\begin{array}{l}2.99 \\
( \pm 0.22)\end{array}$ & $\begin{array}{l}3.08 \\
( \pm 0.27)\end{array}$ & $\begin{array}{l}3.46 \\
( \pm 0.45)^{*}\end{array}$ & $\begin{array}{l}3.60 \\
( \pm 0.38)\end{array}$ & $\begin{array}{l}2.95 \\
( \pm 0.23)\end{array}$ & $\begin{array}{l}2.52 \\
( \pm 0.21)\end{array}$ & $\begin{array}{l}2.41 \\
( \pm 0.27)\end{array}$ & $\begin{array}{l}2.22 \\
( \pm 0.15)\end{array}$ \\
\hline Extract $600 \mathrm{mg} / \mathrm{kg}$ & $\begin{array}{l}3.35 \\
( \pm 0.40)\end{array}$ & $\begin{array}{l}3.39 \\
( \pm 0.41)^{*}\end{array}$ & $\begin{array}{l}3.71 \\
( \pm 0.51)^{*}\end{array}$ & $\begin{array}{l}4.00 \\
( \pm 0.60)^{*}\end{array}$ & $\begin{array}{l}3.36 \\
( \pm 0.50)\end{array}$ & $\begin{array}{l}2.93 \\
( \pm 0.42)\end{array}$ & $\begin{array}{l}2.29 \\
( \pm 0.99)\end{array}$ & $\begin{array}{l}2.38 \\
( \pm 1.08)\end{array}$ \\
\hline $\begin{array}{l}\text { Dihydrocodeine } 0.5 \mathrm{mg} / \mathrm{kg} \text { (positive } \\
\text { control) }\end{array}$ & $\begin{array}{l}3.42 \\
( \pm 0.40)\end{array}$ & $\begin{array}{l}3.98 \\
( \pm 0.46) *\end{array}$ & $\begin{array}{l}4.25 \\
( \pm 0.21)^{*}\end{array}$ & $\begin{array}{l}4.44 \\
( \pm 0.03) *\end{array}$ & $\begin{array}{l}4.52 \\
( \pm 0.03)^{*}\end{array}$ & $\begin{array}{l}4.16 \\
( \pm 1.19)^{*}\end{array}$ & $\begin{array}{l}3.44 \\
( \pm 0.60)\end{array}$ & $\begin{array}{l}2.45 \\
( \pm 0.67)\end{array}$ \\
\hline
\end{tabular}

*This indicates the time intervals that are significant $(\mathrm{P}<0.05)$ when compared to the negative control for the respective pretreatments

Comparing the negative control with the intervention types, the extract at the dose of $200 \mathrm{mg} / \mathrm{kg}$ showed a reduction in the yeast induced increase in rectal temperature which was continuously significant for 2 hours. The extract at the dose of $400 \mathrm{mg} / \mathrm{kg}$ demonstrated similar pattern for up to 2.30 hours while the extract at the dose of $600 \mathrm{mg} / \mathrm{kg}$ however produced a significant reduction in yeast induced increase in rectal temperature for up to 24 hours post administration of oral dose of the extract. Furthermore, the drug Paracetamol (positive control) showed continuous significant change as those produced by the extract for up to 2.30 hours. These patterns of effects suggest that the plant extract has an antipyretic effect which is comparable to those of the standard drug Paracetamol. Table 1.

The results above showed a significant increase in the latency of reaction time (LRT) in the animals for up to 1.30 hours at a dose of $200 \mathrm{mg} / \mathrm{kg}$ and $400 \mathrm{mg} / \mathrm{kg}$ of extract while a significant increase in LRT in the animals for up to 2 hours was observed at a dose of $600 \mathrm{mg} / \mathrm{kg}$. The test drug dihydrocodeine however, showed an effect significant $(\mathrm{P}<0.05)$ as those produced by the extract for up to 3 hours post treatment thus demonstrating that the plant extract possesses an analgesic property which is to a lesser extent comparable to those produced by the drug Dihydrocodeine. Table 2.

\section{DISCUSSION}

The plant extract showed possible signs of the presence of alkaloids, flavonoids and tannins which are secondary metabolites of plants, these secondary metabolites also act in diverse metabolic systems in both humans and animals thus, the exhibition of the dual activity demonstrated by the plant extract. ${ }^{16}$

The individual analgesic and antipyretic effects obtained from this study can be attributed in parts to the presence of flavonoids and tannins as studies has shown that these two phytochemicals especially possess an enzyme inhibitory effect of lipoxygenase and cyclo-oxygenase enzyme 2, resulting in antioxidant and anti-inflammatory effects while tannins possess an antioxidant and antiinflammatory effects by nitric oxide synthetase inhibition. ${ }^{17-20}$ These effects in all cases have demonstrated a reduction in pain and pyrexia mediating prostaglandins which are usually implicated in these conditions. ${ }^{21,22}$ Therefore, the results of this study strongly suggest that the mechanism of action of this extract may be linked to lipoxygenase and/or cyclo-oxygenase enzymes inhibition of phytochemicals like tannins and flavonoids detected in the plant extract.

In pyrexia, the presence of a pyrogenic substances which in this case is produced by the yeast triggers the production of interleukin 1 directly precipitating the production of prostaglandins thus increasing the body's temperature, while the stimulation of pain through heat, chemical or trauma precipitates some level of cell damage and change in cellular nature and membrane which release adenosine triphosphate (ATP) and prostaglandins especially prostaglandin E2 (PGE2) which acts directly on the peripheral nociceptor terminals, reducing their threshold to peripheral stimuli by promoting the phosphorylation of transient receptor potential cation channel, sub family $\mathrm{V}$, member 1 (TRPV1) and other transient receptor potential (TRP) channels, this action increases the terminal membrane excitability by the phosphorylation of the voltage-gated sodium and calcium channels; even those located on the A and $\mathrm{C}$ fibers., $41,23-26$

The central action of PGE2 increases transmitter release from the central terminals of nociception and blockade of glycinergic inhibition, thus low constitutive levels of cyclo-oxygenase enzyme 1 and 2 (COX-1 and COX-2) in the spinal cord generate a short latency, activity-dependent release of PGE2 and peripheral inflammation leads to a large induction of $\mathrm{COX}-2$ in the spinal cord that contributes to inflammation-induced central sensitization and pain. ${ }^{26-29}$ Peripheral sensitization of pain also contributes to pain hypersensitivity within the confines of an inflamed tissue, however the inhibition of prostaglandin synthesis especially PGE2 reduces this pain sensitization and the possible resulting increase in temperature..$^{30,26}$ 
In addition, with the knowledge that analgesic and antiinflammatory effects have been found in flavonoids and tannins, they have also been found to possess ability to inhibit phospholipase A2, phosphodiesterases, protein kinase $\mathrm{C}$ and as earlier mentioned nitric oxide synthetase all of which potentially cause tissue damage and precipitate fever and pain. ${ }^{21-23,31,17}$

Therefore, with the presence of tannins, flavonoids and alkaloids in the plant extract there is a huge possibility of prostaglandin inhibition which resulted in the analgesic and antipyretic effects observed. In addition, the show of greater significant effect of the positive control (i.e. Dihydrocodeine) is suggestive of a better peripheral action of the plant extract as compared to a central action in inhibiting this pain pathway and a better central action of the positive control as compared to a peripheral action in inhibiting this pain pathway. Dihydrocodeine a mu-opioid receptor agonist inhibits adenylate cyclase activity, lowering cyclic adenosine monophosphate (cAMP) levels reducing calcium ion levels in the nerve required for impulse transmission. ${ }^{32}$

These findings finally were found to be consistent with reports by which reported that the methanolic extract of the plant Cleome viscosa has analgesic and antipyretic effects. ${ }^{1,2,12}$ Also, in relation to the study the use of the yeast induced pyrexia technique is because yeast (Saccharomyces cerevisiae) produces pyrogenic agents which act indirectly in the living system to produce pyretic effects, while the application of heat causes mild tissue damage with the release of ATP and stimulation of TRP channels of pain mediation. ${ }^{33}$

\section{CONCLUSION}

In conclusion, this study has shown that the methanolic extract of Cleome viscosa does possess a significant $(\mathrm{P}<0.05)$ antinociceptive and antipyretic effect in laboratory rats at the various doses adopted. These results however support the use of this plant in traditional medicine practice by various traditional medicine practitioners (TMPs) in treatment of febrile convulsion and earache in children.

\section{Recommendations}

This study having provided such results as above even to the possible presence of active phytochemicals, therefore suggest that further investigation and elucidation be conducted on the plant Cleome viscosa to further determine the chronic toxicity profile of the plant, identify, isolate and characterizes the major active principles in the crude extract and for the determination of the possible mechanism of action of the extract. This is in the view that one day the use of Cleome viscosa in traditional medical practice will be exploited even in orthodox medicine to reduce the cost of medical health care in the country.

\section{ACKNOWLEDGEMENTS}

This research work would not be considered complete without due appreciation to the many people whose assistance gave us the inspiration and idea to prepare this work.

Authors gratitude goes first to God Almighty for giving them the grace and all that it takes to see to the successful end of this study.

Authors appreciate Prof. Isah Hussaini and Dr. Garba U. Sadiq of the Department of pharmacology, University of Maiduguri, Nigeria for their constant guidance and supervision. Their sincere gratitude also goes to Engr. Ali (Herbalist) and Mr. Goodness (Laboratory technologist) for their support during plant collection and laboratory work respectively.

\section{Funding: No funding sources}

Conflict of interest: None declared

Ethical approval: The study was approved by the Institutional Ethics Committee of University of Maiduguri, Borno state, Nigeria as over seen by Prof. Isah Hussaini and Dr. Garba U. Sadiq

\section{REFERENCES}

1. Mali RG. Cleome viscosa (wild mustard): A review on ethnobotany, phytochemistry, and pharmacology. Pharmaceutical biology. 2010;48(1):105-12.

2. Mandal SC, Devi BP, Boominathan, R. Evaluation of antipyretic potential of Cleome viscosa Linn. (Capparidaceae) extract in rats. J Ethonopharmacol. 2003;87(1):11-3.

3. Hainline B, Turner JA, Caneiro JP, Stewart M, Moseley GL. Pain in elite athletes-neurophysiological, biomechanical and psychosocial considerations: a narrative review. Br J Sports Med. 2017;51(17):125964.

4. Guyton AC, Hall JE. Textbook of Medical Physiology. $11^{\text {th }}$ Edn. Elsevier Saunders, Philadelphia, USA; 2006.

5. Woolf CJ, Mannion RJ. Neuropathic pain aetiology, symptoms mechanism and management. The Lancef. 1999;353(9168):1059-64.

6. Axelrod YK, Diringer MN. Temperature management in acute neurologic disorder. Neurol Clin. 2008;26(2):585-603.

7. Saund-levander M, Forsberg CJ, Wahren LK. Normal oral, rectal, tympanic and auxiliary body temperature in adult men and women: A systemic literature review. Scand J. Caring Sci. 2002;16(2):122-8.

8. Karakitsos D, Karabinis A. Hypothermia therapy after traumatic brain injury in children. N. Engl J Med. 2008;359(11):1179-80.

9. Brown AK, Christo PJ, Wu CL. Strategies for postoperative pain management: Best practice and research. Clin Anaesth. 2004;18(4):703-17. 
10. Sofowora A. Medicinal Plants and Traditional Medicine In Africa. Spectum Books Ltd, Ibadan; 2008.

11. Eliza. Everything you need to know about an old physician's alternative medicine practice. Natural Health and Nutrition Class. Ladat.Com; 2011.

12. Mandal SC, Devi BP, Boominathan R. Studies on analgesic activity of Cleome viscosa in mice. Fitoterpia. 2003;74(3):262-6.

13. Vogel GH. Drug Discovery and Evaluation: Pharmacological Assays. 2 ${ }^{\text {nd }}$ edn. (Ed. G.H. Vogel). Springer, Germany; 2002:772-774.

14. Jadhav GB, Upasani CD. Analgesic effect of silymarin in experimental induced pain animal models. J Pharm Res. 2009;2(8):1276-8.

15. Milad SB, Mahmoud A, Nehme CL, Pilcher CWT. Antinociceptive action of intrathecally administered IGF-I and the expression of its receptor in rat spinal cord. Brian Res. 1996;737(1-2):292-4.

16. Evans C. Trease and Evans Pharmacognosy. $16^{\text {th }}$ Edn. Saunders/Elsevier, London;2009.

17. Lee JH, Kim GH. Evaluation of antioxidant and inhibitory activities for different subclasses flavonoids on enzymes for rheumatoid arthritis. J Food Sci. 2010;75(7):H212-7.

18. Buhler DR, Miranda JC. Antioxidant activities of flavonoids. The Linus Pauling Institute, Oregun State University; 2000.

19. Manthey JA, Grohmann K, Guthrie N. Biological properties of citrus flavonoids pertaining to cancer and inflammation. Curr Med Chem. 2001;8:135-53.

20. Srivastava RC, Hussain MM, Hassan SK, Athar M. Green tea polyphenols and tannic acid act as potent inhibitors of phorbol esters induced nitric oxide generation in rat hepatocytes independent of their antioxidant properties. Cancer Lett. 2000;153:1-5.

21. Gray PD, Robinson KM, Carncer KL. Alteration of the reproductive system. In: Pathphysiology: The Basis for Disease in Adults and Children. $2^{\text {nd }}$ Edn. Mosby. 1998;745-799.

22. Huether ST, Kravite M. Structure function and disorders of the integument. In: Pathophysiology: The Biologic Basis for Disease in Adults and Children. $2^{\text {nd }}$ Edn. Mobsy; 1998:1512-1560.

23. Emer MS, Garret AF. The ecsaoids: prostaglandins; thromboxane; leukotrenes and related compounds. In: Basic and Clinical Pharmacology. 10 ${ }^{\text {th }}$ Edn. (Ed. B.G. Katzung). McGraw Hill, USA; 2007:293-308.
24. Lopshire JC, Nicol GP. The cAMP transduction cascade mediates the prostaglandin E2 enhancement of the capsaicin elicited current in rats sensory neurons: Whole cell and single channel studies. J Neurosci. 1998;18:6081-92.

25. Smith JA, Davis CL, Burgess CM. Prostaglandin E2 induced sensitization of bradykinin evoked response in rat dorsal root ganglion neurons is mediated by cAMP dependent protein kinase A Eur J Neuro Sci. 2000;12:3250-8.

26. Woolf CJ, Lin C, Anaya F, Barrett L, Wang H, Takada J, et al. Prostaglandin E2 receptor EP4 contributes to inflammatory pain hypersensitivity. J Pharmacol Expt Therap. 2006;319(3):1096-103.

27. Harvey RJ, Depner UB, Wässle H, Ahmadi S, Heindl C, Reinold H, et al. GlyR $\alpha 3$ : an essential target for spinal PGE2-mediated inflammatory pain sensitization. Science. 2004 May 7;304(5672):884-7.

28. Vasko MR. Prostaglandin-induced neuropeptide release from spinal cord. InProgress in brain research 1995 Jan 1;104:367-80. Elsevier.

29. Samad TA, Moore KA, Sapirstein A, Billet S, Allchorne A, Poole S, et al. Interleukin-1 $\beta$-mediated induction of Cox-2 in the CNS contributes to inflammatory pain hypersensitivity. Nature. 2001 Mar;410(6827):471.

30. Mandal AK, Zhang Z, Kim SJ, Tsai PC, Mukherjee AB. Cutting edge: yin-yang: balancing act of prostaglandins with opposing functions to regulate inflammation. The Journal of Immunology. 2005 Nov 15;175(10):6271-3.

31. Mohammed A, Adelaiye AB, Abubakar MS, Abdurahman EM. Effects of aqueous extract of Ganoderma lucidum on blood glucose levels of normoglycemic and alloxan-induced diabetic wistar rats. J of Med Pla Resea. 2007 Sep 30;1(2):034-7.

32. Al-Hasani, R, Bruchas MR. Molecular Mechanisms of Opioid Receptor-Dependent Signaling and Behavior. Anesthesiology. 2011;115(6):1363-81.

33. Ford J. Sterile pharmaceutical products. In: Hugo and Russell's Pharmaceutical Microbiology. $7^{\text {th }}$ Edn. (Eds. S.P. Denger, H. Norman and J. Gorman). Blackwell publishing, USA; 2004:323-345.

Cite this article as: Opara $\mathrm{CO}$, Usman $\mathrm{K}$. Evaluation of the analgesic and antipyretic properties of African Cleome viscosa. Int J Basic Clin Pharmacol 2018;7:1220-5. 